AGRITECH, Vol. 37, No. 4, November 2017, Hal. 410-419

DOI: http://doi.org/10.22146/agritech.13025

ISSN 0216-0455 (Print), ISSN 2527-3825 (Online)

Tersedia online di https://jurnal.ugm.ac.id/agritech/

\title{
Pengaruh Jenis Asam dalam Isolasi Gelatin dari Kulit Ikan Nila (Oreochromis niloticus) terhadap Karakteristik Emulsi
}

\section{Effect of Acid Type in Isolation of Gelatin from Nila Fish (Oreochromis niloticus) Skin on Characteristics of Emulsion}

\author{
S. Suryanti ${ }^{1 *}$, Djagal Wiseso Marseno ${ }^{2}$, Retno Indrati ${ }^{2}$, Hari Eko Irianto ${ }^{1}$ \\ ${ }^{1}$ Pusat Penelitian dan Pengembangan Daya Saing Produk dan Bioteknologi \\ Kelautan dan Perikanan, Jl. K.S. Tubun, Petamburan VI, Jakarta 12060, Indonesia \\ ${ }^{2}$ Departemen Teknologi Pangan dan Hasil Pertanian, Fakultas Teknologi Pertanian, Universitas Gadjah Mada, \\ Jl. Flora No. 1, Bulaksumur, Yogyakarta 55281, Indonesia \\ Email: suryanti_jkt@yahoo.com
}

Submisi: 24 September 2016; Penerimaan: 16 Mei 2017

\begin{abstract}
ABSTRAK
Isolasi gelatin dari kulit ikan nila (Oreochromis niloticus) dengan dua jenis asam (asam asetat 0,10 M dan asam sitrat 0,05 M) terhadap karakteristik emulsi telah dilakukan untuk mengetahui kemampuan gelatin sebagai emulsifier. Pengamatan terhadap gelatin meliputi berat molekul native dengan non-SDS PAGE (polyacrylamide gel electrophoresis), titik isoelektrik, $\mathrm{pH}$ dan asam amino. Pengamatan terhadap karakteristik emulsi meliputi sifat (aktivitas dan stabilitas), viskositas, ukuran partikel, dan mikrostruktur emulsi serta zeta potensial. Konsentrasi gelatin yang digunakan dalam pembentukan emulsi yaitu $0 \%, 0,5 \%, 1,0 \%, 2,0 \%$, dan 3,0\% dengan menambahkan minyak kedele pada rasio 3:1 (v/v). Hasil penelitian menunjukkan berat molekul gelatin native dari asam asetat $0,10 \mathrm{M}$ adalah $>260 \mathrm{kD}$ sedangkan dari asam sitrat $0,05 \mathrm{M}$ sebesar $260 \mathrm{kD}$. Titik isoelektrik kedua gelatin pada $\mathrm{pH}=8,5$ sedangkan $\mathrm{pH}$ gelatin dari asam asetat $0,10 \mathrm{M}$ sebesar 5,35 dan dari asam sitrat 0,05 M sebesar 4,33. Kandungan asam amino lipofilik dari kedua gelatin lebih banyak daripada asam amino hidrofilik dengan kandungan yang terbesar adalah glisin. Sifat emulsi gelatin dari kedua proses asam tersebut memiliki nilai EAI (Emulsion Activity Index) tertinggi pada konsentrasi 0,5\%, yang semakin menurun dengan semakin meningkatnya konsentrasi. Sebaliknya nilai ESI (Emulsion Stability Index) dan viskositas emulsi semakin meningkat dengan semakin meningkatnya konsentrasi. Ukuran partikel droplet dan mikrostruktur emulsi gelatin dari proses asam asetat $0,10 \mathrm{M}$ lebih besar daripada proses asam sitrat $0,05 \mathrm{M}$ pada konsentrasi yang sama dan menunjukkan peningkatan dengan semakin meningkatnya konsentrasi. Zeta potensial kedua gelatin bernilai positif pada semua konsentrasi dan meningkat dengan semakin besarnya konsentrasi.
\end{abstract}

Kata kunci: Asam; emulsi; ikan; gelatin; kulit

\begin{abstract}
The isolation of gelatin from nila fish (Oreochromis niloticus) skin with two types of acid (acetic acid 0,10 M and citric acid $0,05 \mathrm{M}$ ) was carried out on the characteristics of the emulsion to know the ability of gelatin as an emulsifier. The observation has been made for gelatin including native molecule weight with non-SDS PAGE (polyacrylamide gel electrophoresis), $\mathrm{pH}$, isoelectric point, and amino acid content. The characteristics of emulsion were analysed for the emulsion properties (activity and stability), viscosity, particle size, microstructure, and zeta potential. The concentrations of gelatin used in the formation of the emulsion were $0 \%, 0.5 \%, 1.0 \%, 2.0 \%$, and $3.0 \%$ with soybean oil ratio was $3: 1(\mathrm{v} / \mathrm{v})$. The results showed that the molecular weight of native gelatin from acetic acid $0.10 \mathrm{M}$ was > $260 \mathrm{kD}$, whereas from citric acids $0.05 \mathrm{M}$ was $260 \mathrm{kD}$. The isoelectric point of both gelatin was at $\mathrm{pH} 8.5$ whereas the
\end{abstract}


$\mathrm{pH}$ of gelatin obtained using acetic acid $0.10 \mathrm{M}$ was 5.35 and citric acid $0.05 \mathrm{M}$ was 4.33. The level of lipophilic amino acid was higher than hydrophilic amino acid with the highest amount was glycine. The emulsifying properties of gelatin obatined from both acids reached the highest value of EAI (Emulsion Activity Index) at a concentration of $0.5 \%$ which decreased with the increasing of concentration. In contrary, the value of ESI (Emulsion Stability Index) and viscosity increased with the increasing of concentration. The particle size and microstructure of gelatin emulsion with acetic acid $0.10 \mathrm{M}$ were greater than those with citric acid $0.05 \mathrm{M}$ at the same concentration and showed to increase with the increasing of concentration. Zeta potentials of both gelatin were positive charge at all concentrations which increased with the increasing of concentration.

Keywords: Acid; emulsion; fish; gelatin; skin

\section{PENDAHULUAN}

Bahan tambahan pangan emulsifier sangat diperlukan dalam proses produksi pangan untuk membentuk dan menstabilkan tekstur emulsi. Beberapa produk pangan yang dihasilkan dari sistem emulsi minyak dalam air adalah ice cream, salad dressings, dan mayonais. Emulsi didefinisikan sebagai suatu dispersi dua cairan (minyak dan air) yang tidak dapat tercampur, dimana salah satu cairan terdispersi di dalam cairan lainnya sebagai droplet kecil dengan ukuran berkisar antara 0,1-100 $\mu \mathrm{m}$ (Mc Clement, 2005). Bahan pembentuk emulsi (emulsifier) dibutuhkan untuk dapat menyerap fase minyak dan air hingga terbentuk droplet sebagai fase terdispersi dalam suatu sistem emulsi. Emulsifier umumnya berupa biopolimer yang dapat terabsorpsi secara cepat ke permukaan droplet melalui gugus molekul yang bersifat hidrofilik atau lipofilik hingga membentuk suatu lapisan membran yang dapat melindungi droplet dari kerusakan (Hasenhuettl dan Hartel, 2008).

Gelatin adalah biopolimer yang diperoleh dari proses hidrolisis protein kolagen yang terdapat dalam kulit, jaringan otot, dan tulang hewan. Gelatin diperoleh dari kolagen melalui proses pra-perlakuan secara asam (gelatin tipe A) dengan titik isoelektrik pada $\mathrm{pH} 7-9$ atau basa (gelatin tipe B) dengan titik isoelektrik pada $\mathrm{pH} 4,7-5,4$ (Gelatin Manufacture Institute of America, 2012). Gelatin dari kulit ikan umumnya diperoleh dari pra-perlakuan asam karena jaringan kolagen pada kulit lebih lunak. Perlakuan asam menyebabkan terpotongnya ikatan antara gugus karboksil dan gugus amida dalam molekul kolagen. Struktur molekul kolagen triple helix terpecah menjadi rantai $\alpha$-helix sehingga berat molekul gelatin memiliki kisaran yang luas yaitu 90300 kD (Phillip dan Williams, 2009).

Salah satu komoditi penting dari sektor budidaya perikanan adalah ikan nila (Oreochromis niloticus) yang telah banyak diekspor ke negara Eropa dan Jepang dalam bentuk filet segar beku (fresh frozen). Dari industri filet ikan nila tersebut banyak menghasilkan limbah mencapai $60 \%$ yang meliputi kepala, tulang, kulit, isi perut, dan sisik dengan kandungan protein sekitar 18\% (Peranginangin dkk., 2006).
Dari kandungan protein limbah ikan tersebut dapat diolah menjadi gelatin dengan rendemen tertinggi pada kulit ikan. Isolasi gelatin dari kulit ikan nila dengan pra-perlakuan asam asetat $0,10 \mathrm{M}$ dan asam sitrat $0,05 \mathrm{M}$ menghasilkan rendemen sebesar 25,33\% dan 21,09\% dengan distribusi berat molekul 38-241 kDa dan 23-145 kDa (Suryanti dkk., 2016).

Gelatin memiliki karakteristik thermoreversible gel yaitu dapat berubah bentuk menjadi gel pada suhu dingin (chillroom), sehingga dapat berfungsi sebagai bahan tambahan pangan pembentuk gel. Selain itu, gelatin juga bersifat amphiphilic karena mengandung asam amino yang bersifat hidrofilik dan lipofilik sehingga memiliki aktivitas pada permukaan molekulnya (Ward dan Courts, 1977). Sifat ini menunjukkan gelatin dapat berfungsi sebagai bahan pembentuk dan penstabil emulsi karena dapat terserap pada antarmuka minyak dan air dalam sistem emulsi dan membentuk jaringan polimer (Hattrem dkk., 2015). Gelatin memiliki kemampuan sebagai emulsifier dalam sistem emulsi minyak dalam air (Belitz dkk, 2009).

Penggunaan emulsifier dari protein dalam pangan masih terbatas karena umumnya memiliki titik isoelektrik dalam kisaran $\mathrm{pH}$ 4,5-5,5 sehingga kationik emulsi droplet hanya dapat terjadi pada $\mathrm{pH}$ yang lebih rendah. Fase cairan dalam produk pangan umumnya memiliki $\mathrm{pH}>5,0$ sehingga produk emulsi yang menggunakan emulsifier dari protein akan mengandung droplet bermuatan anion yang dapat menimbulkan oksidasi lemak dengan adanya kation mineral seperti $\mathrm{Fe}^{2+}$ atau $\mathrm{Fe}^{3+}$ yang umumnya terdapat dalam fase air. Gelatin tipe A dapat menjadi alternatif bahan pembentuk dan penstabil emulsi dari protein dalam sistem emulsi minyak dalam air karena dapat membentuk droplet bermuatan kationik pada kisaran pH yang lebih luas (Surh dkk., 2006).

Selain itu berat molekul protein native dan kandungan asam aminonya berkaitan dengan karakteristik emulsi yang ditimbulkan. Perbedaan berat molekul protein dapat merubah karakteristik emulsi yang diketahui dari sifat hidrofobisitas yang ditimbulkan oleh asam amino yang bersifat lipofilik pada permukaan molekul sehingga dapat meningkatkan interaksi potensial ionik molekul protein (Foegeding dan Davis, 2011). Oleh karena itu, penelitian ini bertujuan untuk mengetahui 
pengaruh jenis asam (asetat dan sitrat) dalam isolasi gelatin dari kulit ikan nila terhadap karakteristik emulsi sehingga dapat diketahui kemampuan gelatin sebagai emulsifier. Upaya pendekatan penelitian yang dilakukan untuk mencapai tujuan tersebut meliputi karakterisasi molekul gelatin dan emulsi yang dihasilkan yaitu sifat emulsi, viskositas, ukuran droplet, zeta potensial, dan mikrostruktur emulsi.

\section{METODE PENELITIAN}

\section{Bahan dan Alat}

Bahan utama adalah kulit ikan nila (Oreochromis niloticus) dari PT. Aquafarm di Jawa Tengah, asam asetat, asam sitrat (teknis), dan minyak kedele. Bahan kimia meliputi Akrilamid, N'N'N' Bis-Akrilamid, glycine (Sigma), protein ladder (10-260 kD) (Thermo Scientific), $\mathrm{HCl}, \mathrm{NaOH}$, Tetramethylethylenediamine (TEMED) (Thermo Scientific), ultra tris-base, ammonium persulfate, Coomassie brilliant blue R250 (Sigma), metanol, asam asetat glasial, MQ-water dan standar asam amino UPLC grade (Waters).

Peralatan yang digunakan adalah waterbath shaker merk Memmert dari Jerman, IKA T -25 Ultra turrax Digital High-Speed Homogenizer merk Cole parmer dari Amerika, PAGE (Polyacrylamide gel electrophoresis) merk Amersham Bioscience dari Amerika, Viscometer merk Brookfield tipe LVT dari Amerika, Lambda 25 UV/VIS Spectrophotometer merk PerkinElmer dari Amerika, Particle Size Analyzer merk DelsaMax PRO Beckman Coulter dari Amerika, UPLC (Ultra Performance Liquid Chromatography) Acquity H-Class Waters dari Amerika dengan PDA Detector dan optical light microscope merk Leica ICC50 H dari Switzerland.

\section{Isolasi Gelatin dari Kulit Ikan Nila}

Isolasi gelatin dari kulit ikan nila dilakukan secara asam melalui pra-perlakuan asam asetat $0,10 \mathrm{M}$ dan asam sitrat 0,05 M (Suryanti dkk. 2016). Degreasing dilakukan dengan pencelupan dalam air $\left(60-70{ }^{\circ} \mathrm{C}\right)$ selama 5 - 10 detik dan dilanjutkan dengan pengecilan ukuran kulit nila $\pm(4 \times 4 \mathrm{~cm})$. Pra-perlakuan dengan proses asam yaitu perendaman kulit dalam larutan asam asetat 0,10 M selama 2 jam dan asam sitrat 0,05 M selama 1 jam dengan rasio 1:8 (b/v). Pencucian dalam air bersih hingga $\mathrm{pH}$ mendekati netral dan dilakukan penirisan. Pengecilan ukuran kulit dengan alat homogenizer ( \pm 10 detik) dilanjutkan ekstraksi dengan rasio 1:3 (b/v) pada suhu $80{ }^{\circ} \mathrm{C}$ selama 3 jam. Ekstrak gelatin dikeringkan pada suhu $20-25{ }^{\circ} \mathrm{C}$ selama $48-72$ jam yang dilanjukan dengan penepungan dan pengayakan (ukuran 40 mesh) hingga diperoleh tepung gelatin dari kedua jenis asam.

\section{Analisis Berat Molekul Gelatin Native}

Analisis berat molekul gelatin native menggunakan non SDS PAGE (Polyacrylamide gel electrophoresis) berdasarkan metode yang dikembangkan oleh Biorad Laboratories dengan modifikasi (Anonim, 2016). Gelatin (148 $\mu \mathrm{g})$ dimasukkan ke dalam stacking gel $4 \%$ dan separating gel $8 \%$ yang dijalankan dalam Elektroforesis pada $200 \mathrm{~V}$ dan $65 \mathrm{~mA}$, menggunakan marker protein ladder (10-260 kD) (Thermo Scientific). Semua larutan yang digunakan dalam pembuatan gel dan buffer tidak menggunakan SDS dan mercaptoethanol. Pewarnaan gel dengan Coomassie brilliant blue R250 dan penghilangan warna dengan campuran larutan metanol:asam asetat glasial:akuades dengan rasio sebesar 1:1:8 (v/v/v).

\section{Analisis Titik Isoelektrik}

Analisis titik isoelektrik gelatin berdasarkan metoda Ward dan Courts (1977) dan Wang dkk. (2017). Gelatin 2\% (b/v) diatur $\mathrm{pH}$ pada kisaran 5,5-9,5 (interval 0,5) dengan menambahkan $\mathrm{NaOH} \quad 0,5 \mathrm{~N}$ dan $\mathrm{HCl} \quad 0,5 \mathrm{~N}$. Larutan dipisahkan dari bagian yang tidak larut dengan sentrifugasi pada kecepatan 3000 rpm selama 15 menit pada suhu ruang kemudian supernatant disaring dengan kertas saring Whatman 41. Filtrat dianalisis kandungan protein dengan metode kjeldhal. Kelarutan protein diperhitungkan dengan Persamaan 1.

Kelarutan protein $(\%)=\frac{\mathrm{WW}_{1}}{\mathrm{~W}_{\mathrm{o}}} \times 100$

Keterangan: $\mathrm{W}_{1}=$ kandungan protein dalam supernatan $\mathrm{W}_{\mathrm{o}}=$ kandungan protein dalam sampel

\section{pH Gelatin}

Larutan gelatin 1\% dari diukur dengan menggunakan pH meter pada suhu kamar (Ward dan Courts, 1977).

\section{Komposisi Asam Amino}

Sampel gelatin $(0,1 \mathrm{~g})$ dihidrolisis dengan $\mathrm{HCl} 6$ $\mathrm{N}$ selama 23 jam pada suhu $110{ }^{\circ} \mathrm{C}$ kemudian difiltrasi. Sebanyak $10 \mu \mathrm{L}$ larutan yang terdiri dari filtrat sampel, AABA (alpha amino butyric acid) dan aquabides ditambahkan $70 \mu \mathrm{L}$ AccQ-flour borat dan $20 \mu \mathrm{L}$ reagen flour A (6-aminoquinolyl$\mathrm{N}$-hydroxysuccinimidyl carbamate) dihomogenisasi dengan vortex dan diamkan 1 menit. Kemudian inkubasi dilakukan pada suhu $55^{\circ} \mathrm{C}$ selama 10 menit dan sampel siap disuntikkan ke UPLC. Larutan standar disiapkan dengan $40 \mu \mathrm{L}$ standar asam amino dan $40 \mu \mathrm{L}$ internal standar AABA (alpha amino butyric acid) dan $920 \mu \mathrm{L}$ aquabides dihomogenisasi. Sebanyak $10 \mu \mathrm{L}$ larutan standar ditambah $70 \mu \mathrm{L}$ AccQ-flour borate dan $20 \mu \mathrm{L}$ reagen flour A. Inkubasi dilakukan pada suhu $55^{\circ} \mathrm{C}$ selama 10 menit dan standar siap disuntikkan ke 
UPLC. Analisis asam amino menggunakan UPLC H-Class dengan kolom ACCQ-Tag Ultra C18 (2,1 × 100 mm), suhu 49 ${ }^{\circ} \mathrm{C}$, fase gerak dengan sistem komposisi gradient (acetonitril dan akuades), laju alir 0,7 mL per menit, detektor PDA, panjang gelombang $260 \mathrm{~nm}$ dan volume injeksi $1 \mathrm{uL}$. Standar asam amino digunakan untuk memperhitungkan konsentrasi asam amino yang terdapat dalam sampel (Nollet, 1996 dan Anonim, 2012).

\section{Pembuatan Emulsi}

Pembuatan emulsi gelatin berdasarkan Ktari dkk. (2014), Ahmad dan Benjakul (2011). Gelatin (0\%; 0,5\%; $1,0 \% ; 2,0 \%$; dan 3,0\%) ditambahkan minyak kedele dengan rasio $3: 1(\mathrm{v} / \mathrm{v})$ kemudian dihomogenasi pada kecepatan 7000 rpm selama 3 menit pada suhu kamar.

\section{Sifat Emulsi}

Emulsion Activity Index (EAI) dan Emulsion Stability Index (ESI) diperhitungkan berdasarkan Pearce dan Kinsella (1978) dan Ahmad dan Benjakul (2011) dengan Persamaan 2 dan 3.

$$
\begin{aligned}
\operatorname{EAI}(\mathrm{m} 2 / \mathrm{g}) & =\frac{2 \times 2,303 x A o x F p}{\phi x C x l} \\
\operatorname{ESI}(\text { menit })= & \frac{A o}{(A o-A 10)} x \Delta t \\
\text { Keterangan: } \quad \text { A0 } & =\text { Absorban pd } 500 \mathrm{~nm}(\text { menit ke-0) } \\
\text { A10 } & =\text { Absorban pd } 500 \mathrm{~nm}(\text { menit ke-10) } \\
\Delta \mathrm{t} & =10 \text { menit } \\
\text { Fp } & =\text { Faktor pengenceran } \\
\varnothing & =\text { Fraksi minyak }(0,25) \\
\mathrm{C} & =\text { Konsentrasi gelatin }\left(\mathrm{g} / \mathrm{m}^{3}\right) \\
1 & =\text { Panjang kuvet }(\mathrm{m})
\end{aligned}
$$

\section{Viskositas Emulsi}

Viskositas emulsi ditentukan dengan menggunakan alat viscometer brookfield LV dengan spindle nomor 2 pada kecepatan 30 rpm (Shakila dkk., 2012 modifikasi).

\section{Ukuran Partikel Emulsi dan Zeta Potensial}

Ukuran partikel emulsi gelatin dan nilai zeta potensial diukur berdasarkan metoda Hattrem dkk. (2015) yang dimodifikasi. Emulsi gelatin ditambahkan ke dalam MQ water dengan rasio 1:100 (v/v) pada suhu kamar dan di vortex selama 10 detik. Ukuran partikel emulsi dan zeta potensial diukur dengan alat Particle Size Analyzer (Delsa Max PRO. Beckman Coulter). Pengukuran berdasarkan pada intensitas penyebaran cahaya laser terhadap larutan emulsi dan kemudian dapat diketahui distribusi ukuran diameter partikel droplet dan zeta potensial.

\section{Mikrostruktur Emulsi}

Pengamatan mikrostruktur emulsi menggunakan optical light microscope (Leica ICC50 H) yang dilengkapi dengan kamera dengan perbesaran 40 kali (Gao dkk., 2017).

\section{Analisis Data}

Semua data (kecuali berat molekul native, komposisi asam amino dan mikrostruktur emulsi) disajikan dalam jumlah rata-rata dan dianalisis statistik menggunakan oneway analysis of variant (ANOVA) dengan tingkat signifikansi 95\% dengan program SPSS 16 for Windows. Uji lanjut Duncan's Multiple Range Test (DMRT) dilakukan untuk mengetahui perbedaan diantara perlakuan.

\section{HASIL DAN PEMBAHASAN}

\section{Berat Molekul Gelatin Native dari Kulit Ikan Nila}

Analisis non SDS-PAGE PAGE (non-sodium dedocyl sulfate-polyacrylamide gel electrophoresis) dilakukan untuk mengetahui berat molekul gelatin dalam kondisi native tanpa terdenaturasi. Perlakuan dari kedua proses jenis asam (asam asetat $0,10 \mathrm{M}$ dan asam sitrat $0,05 \mathrm{M}$ ) dalam isolasi gelatin berpengaruh terhadap ukuran berat molekul gelatin native yang dihasilkan dapat terlihat pada Gambar 1. Dari Gambar 1 diketahui berat molekul gelatin native dari kulit ikan nila dengan proses asam asetat $0,10 \mathrm{M}$ (GAs) sebesar > $260 \mathrm{kD}$ lebih besar daripada dengan proses asam sitrat 0,05 M (GSi) $260 \mathrm{kD}$. Asam sitrat memiliki banyak gugus yang terionisasi yaitu ion $\mathrm{H}^{+}$yang reaktif dalam jumlah banyak dapat memecah molekul kolagen lebih cepat (Niu dkk, 2013), sehingga dihasilkan gelatin GSi dengan berat molekul native yang lebih rendah.

Dari Gambar 1 juga dapat diketahui molekul gelatin native GAs mengandung rantai $\gamma$, sedangkan molekul gelatin native GSi mengandung rantai $\beta$. Gelatin memiliki karakteristik molekul yang tidak jauh berbeda dengan kolagen dalam bentuk folding yang masih memiliki distribusi berat molekul yang besar berkisar antara $90-300 \mathrm{kD}$ dan terdiri dari komponen sub unit rantai $\alpha, \beta$, dan $\gamma$. Kisaran berat molekul rantai $\alpha$ sebesar 90 hingga $<200 \mathrm{kD}$, rantai $\beta$ sebesar 200 hingga $<270 \mathrm{kD}$ dan rantai $\gamma$ sebesar 270-300 kD (Phillip dan Williams, 2009; Ahmad dkk., 2017). Sub unit rantai $\gamma$ terdiri dari tiga ikatan kovalen rantai $\alpha$, sedangkan sub unit rantai $\beta$ terdiri dari dua ikatan kovalen rantai $\alpha$. Rantai $\alpha$ terdiri dari $\alpha_{1}$ dan $\alpha_{2}$ dimana rantai $\alpha_{1}$ mengandung sedikit asam amino histidine, tirosin, lisin, banyak mengandung hidroksiprolin dan asam amino lipofilik lainnya seperti valin, leusin, dan isoleusin daripada rantai $\alpha_{2}$ (Ward dan Court, 1977). Kandungan asam amino dalam sub unit molekul gelatin tersebut dapat menimbulkan sifat aktivitas permukaan 


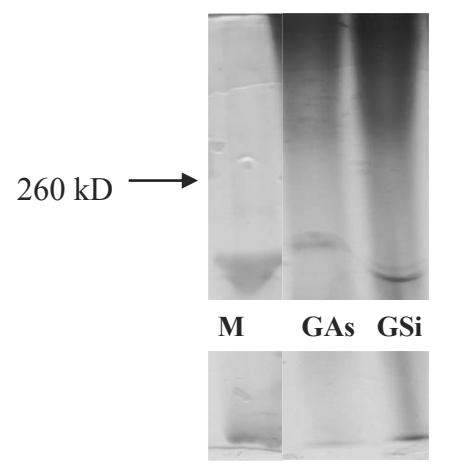

Gambar 1. Berat molekul gelatin native kulit ikan nila dari proses asam asetat $0,10 \mathrm{M}(\mathrm{GAs})$ dan asam sitrat $0,05 \mathrm{M}(\mathrm{GSi})$, marker protein ladder (M)

molekul gelatin yang berbeda pada antarmuka minyak dan air dalam sistem emulsi.

\section{Titik Isoelektrik}

Titik Isoelektrik gelatin kulit ikan nila dengan asam asetat $0,10 \mathrm{M}$ (GAs) dan asam sitrat 0,05 M (GSi) dapat dilihat pada Gambar 2. Gambar 2 menunjukkan titik isoelektrik gelatin dari kulit ikan nila dari GAs dan GSi yaitu pada $\mathrm{pH}$ 8,5 dengan perbedaan yang nyata $(p<0,05)$ pada jenis asam yang sama.

Nilai kelarutan gelatin yang tinggi pada nilai $\mathrm{pH}$ jauh dari titik isoelektrik menunjukkan daya elektrostatik yang tinggi pada molekul gelatin (Ahmad dan Benjakul, 2011). Berdasarkan standar mutu gelatin dari Gelatin Manufacture Institute of America (Anonim, 2012), titik isoelektrik gelatin tipe A yang diperoleh dari proses asam berada pada $\mathrm{pH}$ 7-9.

Pada pH 8,5 kelarutan gelatin GSi (38,32\%) lebih besar dari pada GAs (30,83\%). Asam sitrat memiliki daya ionisasi yang lebih besar daripada asam asetat karena terdapat ion $\mathrm{H}^{+}$yang reaktif lebih banyak (Niu dkk, 2013). Hal ini menyebabkan rantai $\alpha$ dalam struktur sekunder molekul

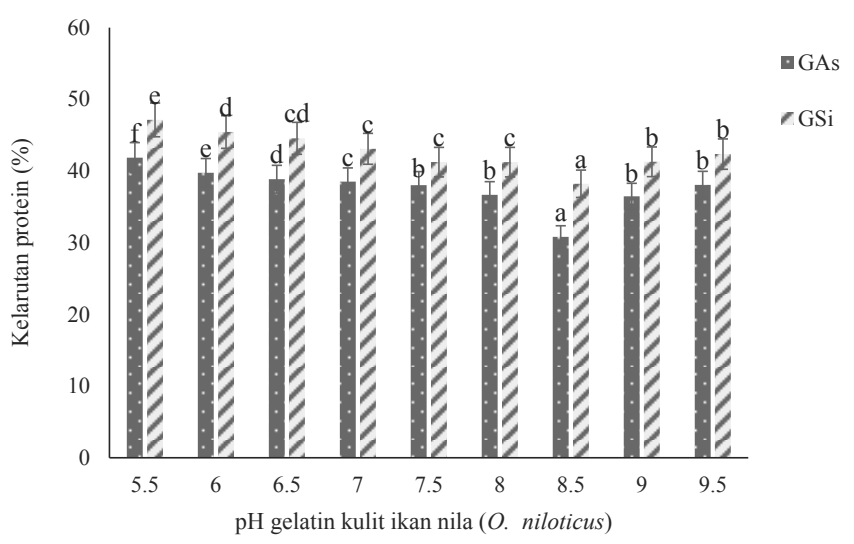

Gambar 2. Kelarutan protein gelatin dari kulit ikan nila dari proses asam asetat $0,10 \mathrm{M}$ (GAs) dan proses asam sitrat 0,05 M (GSi) kolagen triple helix banyak yang terlepas sehingga lebih banyak yang terlarut.

\section{pH Gelatin}

Nilai pH gelatin dari kulit ikan nila dari proses praperlakuan asam asetat $0,10 \mathrm{M}$ (GAs) dan asam sitrat $0,05 \mathrm{M}$ (GSi) dapat dilihat pada Gambar 3. pH gelatin GAs sebesar 5,35 lebih tinggi daripada gelatin GSi 4,33 dengan perbedaan yang nyata $(p<0,05)$.

Nilai $\mathrm{pH}$ gelatin berpengaruh terhadap karakteristik emulsi yang terbentuk. $\mathrm{pH}$ gelatin yang rendah dan jauh dari nilai titik isoelektrik dapat meningkatkan kelarutan gelatin sehingga dapat meningkatkan interaksi muatan elektron dalam molekul gelatin dengan molekul minyak dan air dalam sistem emulsi. Hal ini menyebabkan emulsi yang terbentuk dari gelatin akan memiliki aktivitas dan stabilitas yang tinggi.

Asam sitrat memiliki daya ionisasi yang lebih besar daripada asam asetat karena memiliki beberapa grup molekul terionisasi yaitu terdapat ion $\mathrm{H}^{+}$yang reaktif pada struktur molekulnya yang terdiri dari tiga karboksilat (Vancik, 2014). Hal ini menyebabkan asam sitrat lebih banyak memotong ikatan rantai gugus karboksil dan amida dalam molekul kolagen sehingga $\mathrm{pH}$ gelatin dari proses asam sitrat menjadi lebih rendah.

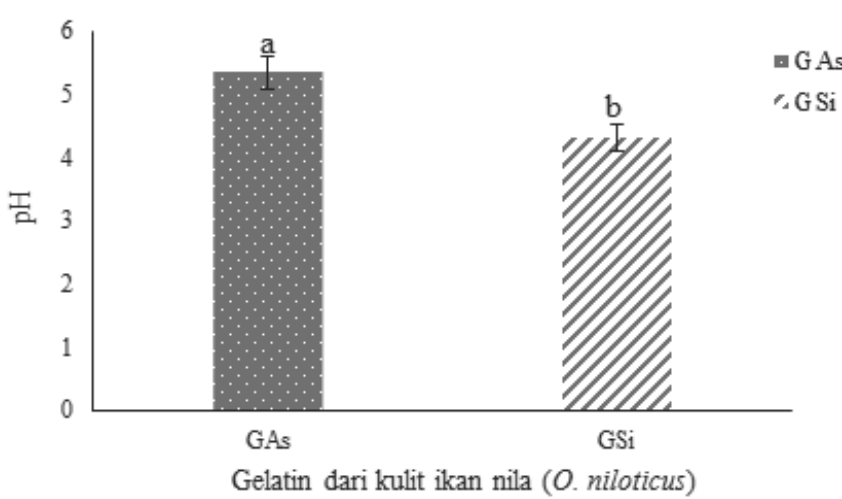

Gambar 3. $\mathrm{pH}$ gelatin dari kulit ikan nila dari proses asam asetat $0,10 \mathrm{M}$ (GAs) dan proses asam sitrat $0,05 \mathrm{M}(\mathrm{GSi})$

\section{Komposisi Asam Amino}

Komposisi asam amino gelatin kulit ikan nila dari proses pra-perlakuan asam asetat $0,10 \mathrm{M}$ (GAs) dan asam sitrat 0,05 M (GSi) dapat dilihat pada Tabel 1.

Secara keseluruhan, kandungan asam amino pada gelatin GAs lebih banyak daripada GSi dengan jumlah asam amino glisin yang paling besar sedangkan asam amino sistein, metionin, histidin dan methionin dalam jumlah lebih rendah. Gelatin GAs mengandung asam amino glisin sebesar 22,41\%, sedangkan GSi 14,58\%. Gelatin GAs terdapat jumlah yang lebih banyak lainnya adalah prolin, alanine, dan arginin 
Tabel 1. Komposisi asam amino gelatin dari kulit ikan nila dari proses asam asetat $0,10 \mathrm{M}(\mathrm{GAs})$ dan dari proses asam sitrat $0,05 \mathrm{M}(\mathrm{GSi})$

\begin{tabular}{|c|c|c|c|}
\hline Asam amino & GAs $(\%)$ & GSi (\%) & Jenis \\
\hline Histidin & 0,90 & 1,47 & hidrofilik \\
\hline Lisin & 3,10 & 5,92 & hidrofilik \\
\hline Arginin & 8,35 & 1,92 & hidrofilik \\
\hline $\begin{array}{c}\text { Asam } \\
\text { aspartat }\end{array}$ & 3,63 & 5,36 & hidrofilik \\
\hline $\begin{array}{c}\text { Asam } \\
\text { glutamat }\end{array}$ & 7,46 & 10,48 & hidrofilik \\
\hline Tirosin & 0,57 & 2,16 & hidrofilik \\
\hline Serin & 3,42 & 3,81 & hidrofilik \\
\hline Treonin & 2,84 & 5,22 & hidrofilik \\
\hline Sistein & 0,01 & 0,58 & hidrofilik \\
\hline Asparagin & - & - & hidrofilik \\
\hline Glutamin & - & - & hidrofilik \\
\hline Jumlah & 30,37 & 36,92 & \\
\hline Glisin & 22,41 & 14,58 & lipofilik \\
\hline Alanin & 7,66 & 2,75 & lipofilik \\
\hline Prolin & 10,65 & 3,84 & lipofilik \\
\hline Metionin & 0,99 & 1,61 & lipofilik \\
\hline Valin & 1,73 & 3,36 & lipofilik \\
\hline Isoleusin & 1,00 & 3,73 & lipofilik \\
\hline Leusin & 2,60 & 6,75 & lipofilik \\
\hline Fenilalanin & 2,16 & 2,72 & lipofilik \\
\hline Triptofan & - & - & lipofilik \\
\hline Jumlah & 49,20 & 39,34 & \\
\hline
\end{tabular}

daripada gelatin GSi. Hal ini sesuai dengan karakteristik utama penyusun molekul kolagen yang sebagian besar adalah asam amino glisin (Ward dan Court, 1977). Shyni dkk. (2014) menyatakan gelatin dari kulit ikan shark, gelatin dari kulit ikan rohu, dan gelatin kulit ikan tuna mengandung asam amino paling banyak yaitu glisin masing-masing sebesar 33,8\%, $33,4 \%$, dan 33,2\%, sedangkan kandungan asam amino glisin dalam gelatin dari kulit ikan red snaper dan white check shark sebesar 22,88\% dan 22,86\% (Pranoto dkk., 2011).

Selain itu, karakteristik spesifik molekul gelatin juga diketahui dari kandungan asam amino prolin dan hidroksiprolin. Hidroksiprolin merupakan turunan dari asam amino prolin yang diperoleh dari hidroksilasi prolin. Balti dkk. (2011) menyatakan asam amino prolin dan hidroksiprolin berperan dalam stabilitas struktur molekul kolagen triple helix melalui ikatan hidrogen diantara molekul air bebas dan grup hidroksil dari prolin dan hidroksiprolin. Tabel 1 menunjukkan kandungan asam amino prolin pada gelatin dari proses asam asetat $0,10 \mathrm{M}(10,65 \%)$ lebih besar daripada asam sitrat 0,05 M (3,84\%). Kandungan prolin yang rendah menunjukkan terlepasnya ikatan molekul triple helix kolagen sehingga kekuatan gel gelatin yang dihasilkan menjadi rendah. Gelatin dari kulit ikan nila dari proses asam asetat $0,10 \mathrm{M}$ dan asam sitrat sebesar 346,16 g bloom dan 134,52 g bloom (Suryanti dkk., 2016).

\section{Sifat Emulsi}

Sifat emulsi protein berhubungan dengan kemampuan protein untuk mengurangi tegangan antarmuka molekul minyak dan air yaitu dengan teradsorpsinya protein pada antar permukaan molekul air dan minyak. Adsorpsi protein dalam sistem emulsi dipengaruhi oleh beberapa faktor seperti struktur protein, hidrofobisitas protein dan kondisi larutan protein seperti $\mathrm{pH}$ dan kekuatan ionik (Liu dkk., 2014). Sifat emulsi yang terbentuk dengan penggunaan gelatin dari kulit ikan nila (Oreochromis niloticus) dapat dilihat pada Gambar 4.

Emulsi yang terbentuk dari gelatin kulit ikan nila dengan proses asam asetat $0,10 \mathrm{M}$ memiliki aktivitas emulsi dan stabilitas emulsi yang lebih tinggi daripada proses asam sitrat $0,05 \mathrm{M}$ pada konsentrasi yang sama. Aktivitas emulsi
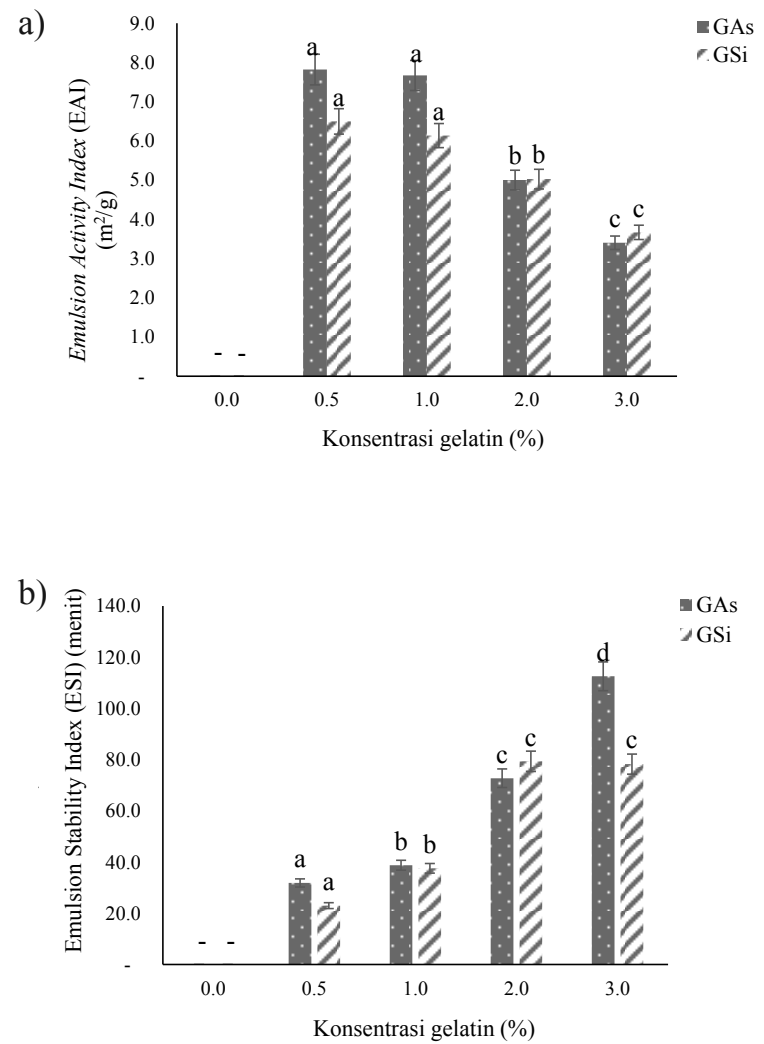

Gambar 4. Sifat emulsi; (a) Emulsion activity index (EAI), (b) Emulsion stability index (ESI) gelatin dari kulit ikan nila dari proses asam asetat $0,10 \mathrm{M}$ (GAs) dan dari proses asam sitrat 0,05 M (GSi) 
gelatin GAs dan GSi yang dihasilkan semakin rendah dengan semakin tingginya konsentrasi $(p<0,05)$. Namun sebaliknya pada stabilitas emulsi akan semakin meningkat dengan semakin tingginya konsentrasi. Hal ini juga ditemukan pada emulsi yang dibentuk oleh gelatin dari kulit ikan unicorn leather jacket (Aluterus monoceros) yang memiliki aktivitas yang semakin rendah dengan semakin besarnya konsentrasi dan stabilitas emulsi semakin meningkat (Ahmad dan Benjakul, 2011).

Aktivitas emulsi tertinggi ditunjukkan pada konsentrasi $0,5 \%$ dari gelatin GAs $\left(7,82 \mathrm{~m}^{2} / \mathrm{g}\right)$ dan GSi $\left(6,45 \mathrm{~m}^{2} /\right.$ g),sedangkan aktivitas emulsi terendah ditunjukkan pada konsentrasi 3,0\% yaitu GAs $\left(3,40 \mathrm{~m}^{2} / \mathrm{g}\right)$ dan GSi $\left(3,65 \mathrm{~m}^{2} / \mathrm{g}\right)$. Stabilitas emulsi terendah pada konsentrasi 0,5\% GAs $(31,95$ menit) dan GSi (23,07 menit), sedangkan stabilitas emulsi tertinggi pada konsentrasi 3,0\% GAs (112,57 menit) dan 2,0\% GSi (79,37 menit). Hal ini menunjukkan bahwa gelatin GAs dan GSi memiliki sifat stabilitas emulsi yang tinggi.

Nilai aktivitas emulsi dari gelatin dari kulit ikan nila jauh lebih rendah daripada gelatin dari kulit ikan kulit ikan unicorn leatherjacket (Aluterus Monoceros) berkisar antara 15,16-39,17 $\mathrm{m}^{2} / \mathrm{g}$ pada kisaran konsentrasi 1-3\% (Ahmad dan Benjakul, 2011). Namun demikian, stabilitas emulsi gelatin dari kulit ikan nila jauh lebih tinggi dibandingkan gelatin dari kulit ikan unicorn leather jacket (Aluterus monoceros) yang berkisar antara 8,57-39,63 menit pada konsentrasi 1,0-,0\% (Ahmad dan Benjakul, 2011), gelatin dari kulit ikan zebra blenny (Salaria basilisca) yang tertinggi 19,7 menit pada konsentrasi 0,5\% (Ktari dkk., 2014).

Korelasi antara aktivitas dan stabilitas emulsi gelatin tidak hanya dipengaruhi oleh berat molekul. Kandungan asam amino yang terdapat dalam molekul gelatin juga berperan dalam pembentukan stabilitas emulsi. Gelatin GAs dengan kandungan asam amino lipofilik lebih banyak (Tabel 1) memiliki aktivitas dan stabilitas emulsi lebih tinggi daripada gelatin GSi. Kandungan asam amino lipofilik pada gelatin GAs sebesar 49,2\% dan hidrofilik 30,37\%. Gelatin GSi mengandung asam amino lipofilik sebesar 39,34\% dan hidrofilik 36,92\%. Kandungan asam amino lipofilik dan hidrofilik yang besar pada gelatin GAs menunjukkan sifat hidrofobisitas yang tinggi sehingga aktivitas dan stabilitas emulsi yang terbentuk oleh gelatin GAs lebih besar daripada gelatin GSi pada konsentrasi yang sama.

Sifat emulsi yang terbentuk dari gelatin dipengaruhi oleh berat molekul dan kandungan asam aminonya. Berat molekul gelatin yang besar mengandung rantai $\beta$ lebih banyak yang dapat menghasilkan stabilitas emulsi yang lebih tinggi daripada gelatin dengan kandungan rantai $\alpha$. Rantai $\beta$ terdiri dari dua rantai $\alpha$ dengan kandungan asam amino yang berbeda (Ward dan Court, 1977) dengan kandungan asam amino yang berbeda. Pada molekul gelatin dari kulit ikan unicorn leatherjacket (Aluterus monoceros) dan zebra blenny (Salaria basilisca) banyak terdapat rantai $\alpha$ dan sedikit rantai $\beta$ (Ahmad dan Benjakul, 2011; Ktari dkk., 2014) sedangkan molekul gelatin native GAs mengandung rantai $\gamma$ dan GSi mengandung rantai $\beta$ (Gambar 1). Berat molekul gelatin yang besar dapat membentuk lapisan antarmuka droplet yang semakin tebal sehingga emulsi yang dihasilkan menjadi lebih stabil.

\section{Viskositas Emulsi}

Viskositas emulsi menunjukkan tekstur kekentalan emulsi yang dihasilkan dari suatu bahan pembentuk emulsi. Nilai viskositas emulsi yang besar menunjukkan stbilitas emulsi yang tinggi. Stabilitas emulsi yang tinggi ditimbulkan oleh adanya interaksi muatan ion yang kuat antara asam amino yang bersifat lipofilik dengan fase minyak dan asam amino yang bersifa lipofilik dengan fase air. Viskositas emulsi yang dibentuk oleh gelatin kulit ikan nila dari proses asam asetat 0,10 M (GAs) dan asam sitrat 0,05 M (GSi) disajikan pada Gambar 5.

Berat molekul gelatin berpengaruh pada nilai viskositas emulsi yang dihasilkan. Nilai viskositas emulsi meningkat dengan semakin meningkatnya konsentrasi gelatin GAs dan GSi. Pola ini sama dengan grafik nilai Emulsion Stability Index (ESI) (Gambar 4b). Viskositas emulsi yang dibentuk oleh GAs lebih tinggi daripada GSi dengan perbedaan yang nyata $(p<0,05)$. Nilai viskositas emulsi tertinggi dibentuk oleh GAs dengan konsentrasi 3,0\% yaitu $150 \mathrm{cps}$, sedangkan viskositas emulsi terendah dibentuk oleh emulsi tanpa penambahan gelatin $(0 \%)$ yaitu 5 cps. Gelatin dengan berat molekul besar lebih banyak mengandung asam amino dengan muatan ionik yang besar sehingga memiliki kemampuan berinteraksi ionik dengan molekul minyak dan air lebih besar dan menyebabkan viskositas emulsi besar.

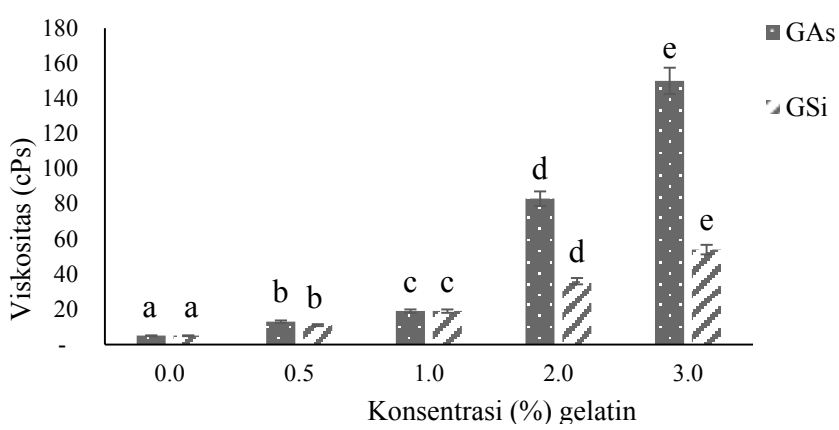

Gambar 5. Viskositas emulsi dari gelatin dari kulit ikan nila dari proses asam asetat $0,10 \mathrm{M}(\mathrm{GAs})$ dan proses asa sitrat $0,05 \mathrm{M}(\mathrm{GSi})$ 


\section{Ukuran Partikel Emulsi}

Ukuran partikel emulsi diketahui dari nilai rata-rata diameter doplet emulsi yang terbentuk dari gelatin kulit ikan nila dari proses asam asetat $0,10 \mathrm{M}$ (GAs) dan asam sitrat $0,05 \mathrm{M}$ (GSi) yang dapat dilihat pada Gambar 6a, sedangkan mikrostruktur emulsi yang terbentuk dapat dilihat pada Gambar 6b. Secara umum, ukuran partikel emulsi yang terbentuk oleh gelatin GAs dan GSi pada konsentrasi yang sama mengalami peningkatan dengan semakin besarnya konsentrasi dan menunjukkan perbedaan yang nyata $(p<$ $0,05)$ pada jenis asam yang sama.

Ukuran partikel emulsi gelatin GAs lebih besar daripada gelatin GSi pada konsentrasi yang sama. Ukuran diameter droplet emulsi terendah pada konsentrasi $0,5 \%$ pada GAs sebesar 1482,9 nm. dan GSi $1420 \mathrm{~nm}$, sedangkan tertinggi pada konsentrasi 3,0\% pada GAs sebesar 1820,9 nm dan GSi $1785,2 \mathrm{~nm}$. Hal ini menunjukkan bahwa dengan semakin besar berat molekul gelatin dapat menghasilkan ukuran partikel emulsi yang semakin besar juga. Berat molekul gelatin native GAs sebesar >260 kD, sedangkan GSi 260 kD (Gambar 1).

Selain itu, komposisi asam amino hidrofilik dan lipofilik berpengaruh pada ukuran partikel emulsi. Gelatin GAs dengan jumlah asam amino hidrofilik dan lipofilik yang lebih besar daripada gelatin GSi (Tabel 1) menghasilkan

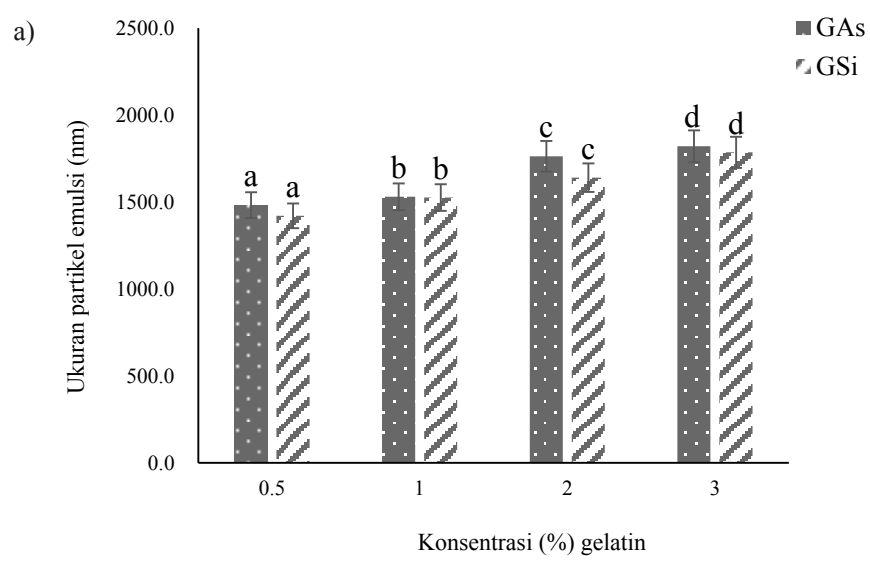

b)

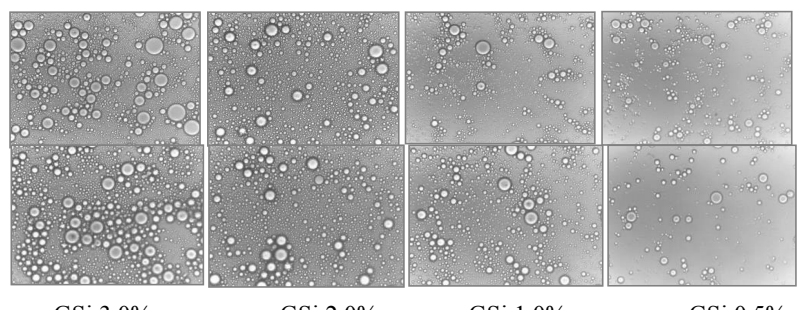

GSi 3,0\%

GSi $2,0 \%$

GSi $1,0 \%$

GSi $0,5 \%$

Gambar 6. Ukuran diameter droplet emulsi gelatin dari kulit ikan nila $(O$. niloticus) dari proses asam asetat $0,10 \mathrm{M}$ (GAs) dan proses asam sitrat $0,05 \mathrm{M}(\mathrm{GSi})$ (a) dan pengamatan emulsi secara visual dengan microscope optic (b) ukuran partikel emulsi yang lebih besar. Gelatin mengandung banyak grup molekul yang terionisasi. Grup molekul gelatin yang terionisasi seperti $\mathrm{COO}-\mathrm{H}^{+}, \mathrm{NH}_{3}^{+}$berasal dari asam amino hidrofilik dan lipofilik (Lam dan Nickerson dkk., 2013) berpengaruh pada pembentukan lapisan droplet emulsi. Semakin besar muatan ion gelatin yang digunakan dalam pembentukan emulsi maka akan semakin besar ukuran partikel emulsi yang terbentuk. Surh dkk. (2006) menyatakan gelatin ikan dengan berat molekul $\sim 55 \mathrm{kD}$ dan $\sim 120 \mathrm{kD}$ menghasilkan ukuran diameter partikel emulsi sebesar 0,35 $\mu \mathrm{m}$ dan $0,71 \mu \mathrm{m}$.

Beberapa jenis asam amino mengandung grup molekul aromatik hidrokarbon yang dapat larut dalam minyak dan hetero atom seperti oksigen, nitrogen dan sulfur yang larut dalam air (Hasenhuettl dan Hartel, 2008). Hal ini dapat mengubah karakteristik elektron pada lapisan antarmuka droplet minyak dan air dalam suatu sistem emulsi seperti yang terlihat pada Gambar 6b. Dari Gambar 6b terlihat mikrostruktur emulsi yang terbentuk dari gelatin GAs dan GSi. Berat molekul native gelatin GAs (>260 kD) dengan kandungan asam amino hidrofilik dan lipofilik yang lebih besar daripada GSi $(260 \mathrm{kD})$ dapat membentuk droplet emulsi berukuran besar. Ukuran droplet emulsi yang besar dihasilkan dari konsentrasi gelatin yang besar dengan muatan ionik yang lebih banyak sehingga emulsi lebih stabil.

\section{Zeta Potensial}

Zeta potensial adalah besarnya muatan elektron pada permukaan droplet partikel dalam suatu sistem emulsi. Dari Tabel 2 diketahui zeta potensial droplet emulsi minyak dalam air dari gelatin kulit ikan nila yang diproses menggunakan asam asetat $0,10 \mathrm{M}(\mathrm{GAs})$ dan asam sitrat $0,05 \mathrm{M}(\mathrm{GSi})$ menunjukkan muatan positif pada semua konsentrasi. Semakin besar konsentrasi gelatin yang digunakan dalam pembentukan emulsi menghasilkan nilai zeta potensial yang

Tabel 2. Zeta potensial gelatin dari kulit ikan nila dari proses asam asetat $0,10 \mathrm{M}(\mathrm{GAs})$ dan proses asam sitrat $0,05 \mathrm{M}(\mathrm{GSi})$

\begin{tabular}{cr}
\hline Konsentasi & Zeta potensial \\
\hline GAs $0,5 \%$ & $+7,64 \pm 2,55^{\mathrm{a}}$ \\
GAs $1,0 \%$ & $+11,45 \pm 1,40^{\mathrm{b}}$ \\
GAs $2,0 \%$ & $+13,60 \pm 0,54^{\mathrm{b}}$ \\
GAs 3,0\% & $+12,74 \pm 2,34^{\mathrm{b}}$ \\
GSi $0,5 \%$ & $+9,06 \pm 0,60^{\mathrm{c}}$ \\
GSi $1,0 \%$ & $+9,90 \pm 0,39^{\mathrm{c}}$ \\
GS 2,0\% & $+12,20 \pm 0,92^{\mathrm{d}}$ \\
GSi 3,0\% & $+14,42 \pm 0,64^{\mathrm{e}}$ \\
\hline
\end{tabular}


semakin besar nilai positifnya $(p<0,05)$. Zeta potensial gelatin GAs dan GSi terbesar pada konsentrasi 3,0\% yaitu $+14,42$, dan $+12,74$.

Liu dkk. (2014) menyatakan gelatin dari babi pada konsentrasi $1,0 \%$ memiliki nilai zeta potensial yang paling besar yaitu $+12,40$ pada $\mathrm{pH} 4$ dibandingkan dengan nilai $\mathrm{pH}$ yang lebih tinggi. Nagarajan dkk. (2015) juga menyatakan zeta potensial larutan gelatin kulit ikan tilapia bermuatan positif pada kondisi $\mathrm{pH}$ asam dan bermuatan negative pada kondisi $\mathrm{pH}$ basa. Hal ini menunjukkan $\mathrm{pH}$ berpengaruh pada besarnya nilai zeta potensial, yaitu dengan semakin besar $\mathrm{pH}$ maka semakin rendah zeta potensial. Zeta potensial juga dipengaruhi oleh nilai titik isoelektrik. Pada $\mathrm{pH}$ lebih rendah dari titik isoelektrik akan bermuatan positif. Zeta potensial droplet emulsi yang dihasilkan oleh gelatin GSi lebih besar nilai positif daripada GAs. Gelatin GSi memiliki nilai pH 4,3 dan GAs memiliki nilai pH 5,4 (Gambar 3) yang berada jauh dibawah titik isoelektriknya 8,5 . Nilai $\mathrm{pH}$ gelatin yang berada dibawah titik isoelektrik akan menimbulkan interaksi ionik positif yang semakin besar dalam molekul gelatin, sehingga menghasilkan permukaan droplet emulsi bermuatan positif.

Berdasarkan uraian hasil penelitian tersebut di atas, dapat diketahui bahwa gelatin kulit ikan nila (O. niloticus) dari proses asam asetat $0,10 \mathrm{M}$ dan asam sitrat $0,05 \mathrm{M}$ memiliki kemampuan sebagai emulsifier yang dapat diaplikasikan dalam produk pangan. Nilai zeta potensial droplet emulsi gelatin yang bermuatan positif semua (Tabel 2) menunjukkan gelatin dapat menstabilkan emulsi dalam waktu lama. Hal ini dikarenakan muatan ion positif dari gelatin dapat mencegah interaksi droplet minyak dengan kation dari mineral $\mathrm{Fe}^{+}$ atau $\mathrm{Fe} 3^{+}$yang umumnya terdapat dalam fase air yang dapat menyebabkan terjadinya oksidasi minyak.

\section{KESIMPULAN}

Gelatin dari kulit ikan nila dari proses asam asetat $0,10 \mathrm{M}$ dan asam sitrat $0,05 \mathrm{M}$ dengan berat molekul native sebesar $>260 \mathrm{kD}$ dan $260 \mathrm{kD}$ memiliki kemampuan sebagai emulsifier dalam produk pangan. Berat molekul gelatin native dan kandungan asam amino berpengaruh pada sifat emulsi beserta karakteristik emulsinya. Aktivitas emulsi gelatin kulit ikan nila dari proses asam asetat $0,10 \mathrm{M}$ dan asam sitrat 0,05 M paling tinggi pada konsentrasi 0,5\% yang semakin menurun dengan semakin meningkatnya konsentrasi, sedangkan stabilitas dan viskositas emulsi semakin meningkat dengan semakin meningkatnya konsentrasi. Selain itu, ukuran partikel dan mikrostruktur emulsi gelatin semakin besar dengan semakin besarnya konsentrasi. Zeta potensial droplet emulsi bermuatan positif pada semua konsentrasi, dimana semakin besar konsentrasi gelatin menghasilkan nilai zeta potensial yang semakin besar. Zeta potensial emulsi dari gelatin yang dihasilkan bermuatan positif tersebut dapat mencegah interaksi droplet minyak dengan kation dari mineral dalam fase air sehingga stabilitas emulsi yang terbentuk tinggi.

\section{UCAPAN TERIMA KASIH}

Penulis mengucapkan terima kasih kepada Pusat Penelitian dan Pengembangan Daya Saing Produk dan Bioteknologi Kelautan dan Perikannan, Kementerian Kelautan dan Perikanan yang telah membiayai penelitian ini melalui anggaran APBN tahun 2016.

\section{DAFTAR PUSTAKA}

Anonim (2012). Waters Acquity UPLC H Class and H Class Bio amino Acid Analysis System Guide. USA.

Anonim (2016). A guide to Polyacrylamide Gel Electrophoresis and Detection. Biorad Laboratories. Life Science Group. California. USA. (www.bio-rad. com/webroot/web/pdf/lsr/literature/Bulletin_6040. [7 Maret 2016].

Ahmad, M. dan Benjakul, S. (2011). Characteristics of gelatin from the skin of unicorn leatherjacket (Aluterus monoceros) as influenced) by acid pretreatment and extraction time. Food Hydrocolloids 25: 381-388.

Badan Standarisasi Nasional (2006). Penentuan kadar protein (SNI 01-2354.4-2006). Jakarta.

Balti, R., Iridi, M., Sila, A., Souissi, N., Nedjar-Arroume, N., Guillochon, D. dan Nasri, M. (2011). Extraction and functional properties of gelatin from the skin of cuttlefish (Sepia officinalis) using smooth hound crude acid protease-aided process. Food Hydrocolloids 25: 943-950.

Belitz, H.D., Grosch, W. dan Scriberle, P. (2009). Food Chemistry. Springer-Verlag Berlin Heidelberg.

Foegeding, E.A. dan Davis, J.P. (2011). Food protein functionality: A comprehensive approach. Food Hydrocolloids 25: 1853-1864.

Gao, Z., Zhao, J., Huang, Y., Yao, X., Zhang, K., Fang, Y., Nishinari, K., Phillips, G., Jiang, F. dan Yang, H. (2011). Edible Pickering emulsion stabilized by proteinfibrils. Part 1: Effects of $\mathrm{pH}$ andfibrils concentration. LWT Food Science and Technology 76: 1-8.

Gelatin Manufacture Institute of America. (2012). GMIA. Gelatin Handbook. http://www.gelatin-gmia.com/ images/GMIA_Gelatin_Manual_2012.pdf.[5 Desember 2013]. 
Hattrem, M.N., Molnes, S., Haug, I.J. dan Draget, K.J. (2015). Interfacial and rheological properties of gelatin based solid emulsions prepared with acid or alkali pretreated gelatins. Food Hydrocolloids 43: 700-707.

Hasenhuetll, G.L. dan Hartel, R.W. (2008). Food Emulsifier and Their Applications. Second Edition. Springer.

Ktari, N., Mourad, I., Rim, N., Imen, L., Hanen, B.A., Barkia, A. dan Moncef, N. (2014). Characteristics and functional properties of gelatin from zebra blenny (Salaria basilisca) skin. LWT - Food Science and Technology 58: 602-608.

Lam, R.S.H., Michael, T. dan Nickerson (2103). Food proteins: A review on their emulsifying properties using a structure-function approach. Food Chemistry 141: 975-984.

Liu, H., Wong, B., Barrow, C.J. dan Adhikari, B. (2014). Relating the variation of secondary structure of gelatin at fish oil-water interface to adsorption kinetics, dynamic interfacial tension and emulsion stability. Food Chemistry 143: 484-491.

Mc. Clement D.J. (2005). Food Emulsions, Principles, Practices, and Techniques. Second Edition. CRC Press. Washington DC.

Niu, L., Zhou, X., Yuan, C., Bai, Y., Yang, F. dan Huang, Y. (2013). Characterization of tilapia (Oreochromis niloticus) skin gelatin extracted with alkaline and different acid pretreatments. Food Hydrocolloids 33: 336-341.

Nagarajana, M., Benjakul, S., Prodpran, T. dan Songlipya, P. (2015). Effects of $\mathrm{pHs}$ on properties of bionanocomposite based on tilapia skin gelatin and Cloisite $\mathrm{Na}+$. International Journal of Biological Macromolecules 75: 388-397.

Nollet, Leo, M.L. (2004). Handbook of Food Analysis. Second Edition, Revised and Expanded. Amino Acid. Marcel Dekker, Inc,.

Pearce, K.N dan Kinsella, J.E. (1978). Emulsifying properties of proteins: evaluation of a turbidimetric technique. Journal of Agric. Food Chem. 26(3).

Peranginangin, R., Taswir, Suryanti dan Lestari D.A. (2006). Optimalisasi Pemanfaatan Limbah Tulang dan Kulit Ikan. Laporan Teknis. Balai Riset Pengolahan Produk dan Bioteknologi Kelautan dan Perikanan. Jakarta.
Phillip, G.O. dan Williams, P.A. (2009). Handbook of Hydrocolloids. Second edition. CRC Press. Washington. DC.

Pranoto, Y., Marseno, D.W. dan Rahmawati, H. (2011). Characteristics of gelatins extracted from fresh and sundried seawater fish skins in Indonesia. International Food Research Journal 18(4): 1335-1341.

Shakila, R.J., Jeevithan, E., Varatharajakumar, A., Jeyasekaran, G. dan Sukumar, D. (2012). Comparison of the properties of multi-composite fish gelatin films with that of mammalian gelatin films. Food Chemistry 135: 2260-2267.

Shyni, K., Hema, G.S., Ninan, G., Mathew, S., Joshy, C.G. dan Lakshmanan, P.T. (2014). Isolation and characterization of gelatin from the skins of skipjack tuna (Katsuwonus pelamis), dog shark (Scoliodon sorrakowah), and rohu (Labeo rohita). Food Hydrocolloids 39: 68-76.

Sinthusamran, S., Benjakul, S. dan Kishimura, H. (2014). Characteristics and gel properties of gelatin from skin of seabass (Latescalcarifer) as influenced by extraction conditions. Food Chemistry 152: 276-284.

Surh, J., Decker, E.A. dan McClement, D.J. (2006). Properties and stability of oil-in-water emulsions stabilized by fish gelatin. Food Hydrocolloids 20: 596-606.

Suryanti, Indrati, R., Irianto. H.E. dan Marseno. D.W. (2016). Comparison study on the extraction of gelatin from nila fish (Oreochromis nilotichus) skin using acetic acid and citric acid. Pakistan Journal of Nutrition 15(8): $777-$ 783.

Vančik, H. (2014). Basic Organic Chemistry for the Life Sciences. Springer Cham Heidelberg New York Dordrecht London.

Ward, A.G. dan Courts, A. (1977). The Science and Technology of Gelatin. Academic Press. London.

Wang, L., Liu, H., Lin, L., Wang, Q., Li, S. dan Li, Q. (2017). Prediction of peanut protein solubility based on the evaluation model established by supervised principal component regression. Food Chemistry 218: 553-560. 